\title{
The effect of continuous treatment with prostaglandin F-2 $\alpha$ on oestrous cycle length and corpus luteum regression in hysterectomized guinea-pigs
}

\author{
E. C.-F. Tso and W. H. Tam \\ Department of Zoology, University of Western Ontario, London, Ontario N6A 5B7, \\ Canada
}

It has been established that prostaglandin (PG) F-2 $\alpha$ induces the involution of corpora lutea (CL) in hysterectomized guinea-pigs (Blatchley \& Donovan, 1969) and that the guinea-pig uterus is probably the major source of this luteolytic factor (Poyser, 1972). However, the measurement of PGF-2 $\alpha$ levels in the utero-ovarian venous plasma of cyclic guinea-pigs (Blatchley, Donovan, Horton \& Poyser, 1972) revealed that, even though the concentration was low, PGF-2 $\alpha$ was present throughout the oestrous cycle and that there was asynchrony in luteal regression (Days 12-16: Rowlands, 1956) and the peak of PGF-2 $\alpha$ secretion (Day 15: Blatchley et al., 1972). During experiments to study the effects of PGF-2 $\alpha$ on the different tissue components of the ovary, it was found that the CL responded to the luteolytic action of PGF- $2 \alpha$ only at certain times.

Guinea-pigs were hysterectomized before puberty (24-32 days old) and then injected i.p. twice every day with $0.125 \mathrm{mg}$ PGF-2 $\alpha$ (equivalent to $0.168 \mathrm{mg}$ THAM salt, Upjohn Co.) in $0.5 \mathrm{ml} 0.9 \%$ $\mathrm{NaCl}$, i.e. $0.057-0.100 \mathrm{mg} \mathrm{PGF}-2 \alpha / 100 \mathrm{~g}$ body weight/day (Group A). Other guinea-pigs of the same age were (i) hysterectomized and injected twice daily with $0.5 \mathrm{ml} \mathrm{NaCl}$ (Group B), (ii) subjected to sham-operation, i.e. sectioning of the utero-vaginal junction but leaving the uterine horns in situ, and similarly treated with $\mathrm{NaCl}$ (Group C), and (iii) given no treatment (Group D). Most animals were killed in the second oestrous cycle, but 3 Group-A and 3 Group-D animals weremaintained until the early stages of the fourth cycle. At autopsy the ovaries were fixed and serially sectioned for histological observation. The CL volume was calculated from the mean of 3 diameters set at right angles to one another, measured with an ocular micrometer from the ovarian sections. Oestrous cycle length was calculated by daily examination of the vaginal closure membrane and the day after the first day the vaginal membrane was fully perforate was taken to be Day 1 of the cycle.

The first vaginal opening was observed in animals of Groups $C$ and $D$ when they were $36.2 \pm 0.8$ $(\mathrm{N}=23$ ) days old (mean \pm S.E.M., the total of 11 animals in Group $\mathrm{C}$ and 12 animals in Group $\mathrm{D}$ ), but the first vaginal opening occurred at $45 \cdot 2 \pm 2.9(\mathrm{~N}=14)$ days of age in the PGF-2 $\alpha$-treated animals in Group A. It is not clear whether this delay was due to the combined effect of hysterectomy and PGF-2 $\alpha$ treatment or just the shock of hysterectomy as the amount of blood loss in hysterectomy was always greater than in the sham-operation. However, once the first oestrus had occurred the cycle lengths in Group A were, for the first to third cycle, 14.9 \pm 0.6 (number of cycles observed =12), $15 \cdot 0 \pm 1 \cdot 2$ (3) and 16.3 \pm 0.9 (3) days, respectively; and these durations were not significantly different (Student's $t$ test) from those of the control animals in Group D $(15.4 \pm 0.6(9), 16.3 \pm 0.3(3)$ and $15 \cdot 7 \pm 0 \cdot 3$ (3) days, respectively). There was also no significant difference between the duration of the first cycle in Groups C and D. Continual treatment with exogenous PGF-2 $\alpha$ did not therefore interfere with ovulation and the formation of CL.

Although continuous treatment with PGF-2 $\alpha$ after hysterectomy did not change the cycle length, luteal volumes were affected (Table 1 ). In Groups $C$ and D luteal volume was maximal between Days 10 and 11 and fell significantly $(P<0.001)$ on Day 14 . The CL volumes (Table 1) obtained on the same day of the cycle were tested for homogeneity by one-way analysis of variance and any significant difference, at a level of $5 \%$, between groups was determined by the Studentized Range (Q method). There was no significant difference in CL volume among Groups A, C and D on Days 5, 9 and 12, but the CL in Group A were significantly smaller than those of Groups C and D on Day 14. This indicates that in Group A, even after hysterectomy and in the continuous presence of exogenous 
Table 1. The effect of prostaglandin F-2 $\alpha$ on luteal volume (mean \pm S.E.M.) in guinea-pigs at various stages of the oestrous cycle (no. of animals, no. of CL)

\begin{tabular}{|c|c|c|c|c|c|}
\hline \multirow[b]{2}{*}{ Group } & \multirow[b]{2}{*}{ Treatment } & \multicolumn{4}{|c|}{ Corpus luteum volume $\left(\mathrm{mm}^{3}\right)$} \\
\hline & & Day 5 & Day 9 & Day 12 & Day 14 \\
\hline A & Hysterectomy and PGF-2 $\alpha$ & $\begin{array}{c}1 \cdot 279 \pm 0 \cdot 041 \\
(1,3)\end{array}$ & $\begin{array}{c}1 \cdot 621 \pm 0 \cdot 133 \\
(2,6)\end{array}$ & $\begin{array}{c}1 \cdot 145 \pm 0 \cdot 211 \\
(2,7)\end{array}$ & $\begin{array}{c}0 \cdot 203 \pm 0 \cdot 021 \\
(2,7)\end{array}$ \\
\hline B & Hysterectomy and saline & $\begin{array}{c}1.526 \pm 0.073 \\
(2,5)\end{array}$ & $\begin{array}{c}2 \cdot 331,2 \cdot 280 \\
(1,2)\end{array}$ & $\begin{array}{c}1 \cdot 780 \pm 0.041 \\
(2,5)\end{array}$ & $\begin{array}{c}2 \cdot 346 \pm 0.154 \\
(2,5)\end{array}$ \\
\hline $\mathrm{C}$ & Sham-operation and saline & $\begin{array}{c}1.487 \pm 0.106 \\
(1,3)\end{array}$ & $\begin{array}{c}1.779 \pm 0.063 \\
(2,7)\end{array}$ & $\begin{array}{c}1.830 \pm 0.065 \\
(2,6)\end{array}$ & $\begin{array}{c}0.786 \pm 0.063 \\
(2,5)\end{array}$ \\
\hline $\mathbf{D}$ & None (control) & $\begin{array}{c}1.452 \pm 0 \cdot 213 \\
(2,6)\end{array}$ & $\begin{array}{c}1 \cdot 973 \pm 0 \cdot 128 \\
(2,7)\end{array}$ & $\begin{array}{c}2.036 \pm 0.155 \\
(2,7)\end{array}$ & $\begin{array}{c}0.994 \pm 0.053 \\
(2,6)\end{array}$ \\
\hline
\end{tabular}

PGF-2 $\alpha$, the growth of CL during the first half of the cycle was normal and that the involution of CL was completed at about the same time as in Groups C and D. Regression of CL in one Group-A animal obviously began on Day 12 as the volume of the three CL was between 0.357 and $0.975 \mathrm{~mm}^{3}$, the four CL of the other animal were comparable with those of Day 9 animals. The histology of the three small CL was more similar to that of Day 14 animals in Groups A, C and D, containing patches of shrunken cells and pyknotic nuclei rather than the healthy-looking luteal cells seen in other Day-12 animals. In Group B regression of the CL had not occurred on Day 14 and the CL volume was significantly larger than those of other groups on Days 9 and 14. One hysterectomized and saline-treated guinea-pig was maintained for 168 days after the operation but the vaginal membrane remained intact throughout this period. The possibility that luteal regression in the Groups $\mathbf{C}$ and $\mathbf{D}$ animals was caused by endogenous ovarian PGF-2 $\alpha$ is therefore unlikely.

These data demonstrate (i) that, in guinea-pigs in which endogenous uterine PGF-2 $\alpha$ is removed by hysterectomy, exogenous PGF- $2 \alpha$ can only induce CL regression after Day 9 of the oestrous cycle, (ii) that luteolysis induced by PGF-2 $\alpha$ occurs at a specific time, and (iii) that approximately 5 days have to elapse between onset of luteolysis and ovulation. The present findings also explain why the oestrous cycle of guinea-pigs is not shortened when endogenous secretion of PGF-2 $\alpha$ is augmented by experimental means or when the animals are given exogenous PGF-2 $\alpha$ (Blatchley \& Donovan, 1976).

This investigation was supported by Grant A6792 from the Canadian National Research Council. The PGF- $2 \alpha$ was a generous gift from Dr J. E. Pike (Upjohn Co.).

\section{References}

Blatchley, F.R. \& Donovan, B.T. (1969) Luteolytic effect of prostaglandin in the guinea-pig. Nature, Lond. 221, 1065-1066.

Blatchley, F.R. \& Donovan, B.T. (1976) Effect of intra-uterine foreign bodies and of prostaglandin administration on progesterone secretion during the oestrous cycle of the guinea-pig. J. Endocr. 70, 39-45.

Blatchley, F.R., Donovan, B.T., Horton, E.W. \& POYSER, N.L. (1972) The release of prostaglandins and progestin into the utero-ovarian venous blood of guinea-pigs during the oestrous cycle and following oestrogen treatment. $J$. Physiol., Lond. 223, 6988.

POYSER, N.L. (1972) Production of prostaglandins by the guinea-pig uterus. J. Endocr. 54, 147-159.

Rowlands, I.W. (1956) The corpus luteum of the guinea-pig. Ciba Foundation Colloquia on Ageing 2, 69-85.

Received 28 October 1976 